\title{
FLIPPING THE SCRIPT: RETHINKING WORKING-CLASS RESISTANCE
}

\author{
HENRY A. GIROUX \\ girouxh@mcmaster.ca \\ McMaster University
}

\begin{abstract}
This article argues that any viable notion of working class resistance will rest on reclaiming those narratives, historical memories, and elements of resistance that provide a sense of meaning, dignity, and working class courage. In too many instances, members of the working class are defined by their deficits, which are used to both depoliticize people and render them as excess and mere refuge. The article also analyzes and makes a case for the importance of historicizing, critically engaging, and breaking through the ways in which working class people are rendered disposable through a variety of ideological, educational, and repressive mechanisms utilized by the ruling elites. In this script, education becomes central to politics and the struggle over agency becomes crucial to what Giroux calls flipping the script. The article makes a call for the creation of working class public intellectuals and a critical formative culture that makes such acts possible at a time of increasing authoritarianism, especially under the Trump regime.
\end{abstract}

Keywords: disposability; education; flipping the script; ideology; politics; resistance; working class

\section{Introduction: Waking to Politics}

I have often thought about when that moment came in which my working class sensibility turned into a form of critical class consciousness. For most of my youth, I was defined by ruling-class types and mainstream institutions through my deficits, which allegedly amounted to not having the skills and capacities to do anything but become either a cop or firefighter. For many working-class youth, this is standard procedure. We are told that we are too angry when we display passion, and too dumb when we speak in the restricted code. Our bodies for both sexes were the only cultural capital we had to define our sense of agency, either through an expression of solidarity, over determined masculinity, or through a commodified and sexualized notion of the body. The message was always the same. We were incomplete, unfinished, excess and disposable. For many of us that meant a life 
governed by poor schools and never escaping the wide reach of the criminal legal system.

I came alive and began to own my own agency when I realized that what the ruling-class types (in a variety of institutions, especially school) called my deficits were actually my strengths: a sense of solidarity, compassion, a merging of the mind and the body, learning and willing to take risks, embracing passion, connecting knowledge to power, and being attentive to the injuries of others and embracing a sense of social justice.

I then realized that I had to flip the script to survive and became acutely aware that the alleged strengths of ruling-class types, such as their, cold, hyper-masculine modes of embodiment, along with their ruthless sense of competitiveness, their suffocating narcissism, their view of unbridled self-interest as the highest virtue, their ponderous and empty elaborated code, and their often savage and insensitive modes of interaction, were actually poisonous deficits. I was particularly struck by their arrogance, infatuation with materialism, their aversion to risk, their lack of moral courage and imagination, their aversion to empathy, and their unwillingness to think about hard issues. That was a turning point in my being able to narrate and free myself from one of the most sinister forms of ideological domination, 'those unexamined prejudices that keep us from thinking' (Knott, 2011: 87).

For me, this involved a slow process of unlearning the poisonous, sedimented histories working-class youth often have to internalize and embody in order to survive. Unlearning meant becoming attentive to the histories, traditions, daily rituals and social relations that offered both a sense of resistance and allowed people to think beyond the inflicted misery and suffering that marked our neighborhoods and daily lives. It meant not only learning about resistance in our lost histories, but also how to narrate oneself from the perspective of understanding both the poisonous cultural capital that shored up ruling-class power and those modes of cultural capital, a kind of underground literacy that allowed us to challenge it. It also meant unlearning those modes of oppression that many working-class youth had internalized, obvious examples being the rampant sexism, racism and hyper-masculinity we had been taught were matters of common sense and reputable badges of identity.

The struggle to redefine my sense of agency was about more than a perpetual struggle between matters of intelligence, competency and low self-esteem; it was about reclaiming a sense of history, opening the door to dangerous memories, and taking risks that enabled a new and more radical sense of identity and what it meant to be in the world from a position of strength. I found signposts of such resistance in my youth in Black music, stories about union struggles, the warm solidarity of my peers, and later in the powerful display of public intellectuals whose lectures I attended at Brown University. The people who moved me at those lectures were not academics reading papers I barely understood, or intellectuals who seemed frozen emotionally, spewing out a kind of jargon reserved for the already initiated, smug in their insularity and remoteness. 
They were public intellectuals such as William Kunstler, Stanley Aronowitz, Angela Davis and Dick Gregory who provided me with an alternative understanding and representations of what a working-class public intellectual might be like. They were larger than life and passionate as they spoke about a range of social injustices. They took over the stage in a display that was as smart as it was performative - their words matched by a stylized show of emotion, empathy, anger and hope. Passion filled their words and their bodies moved in sync with the heightened sense of urgency about which they spoke. They broke open and destabilized the stale language of the academy, 'smuggling in sound, rhythm, and image' (Knott, 2011: 73). Watching and listening to them my political sensibility changed and my ability to narrate myself and my hopes and visions changed in dramatic ways and I never looked back.

Once again we see working-class Black, Brown and white youth reclaiming their histories in the face of massive state violence and terrorism, especially Black youth in the Black Lives Matter and other emerging movements. They are flipping the script in order to rewrite themselves into a massive movement not for reform but for economic and political change - real change in which a radical democracy comes alive with justice and hope for a better future. They are not concerned simply about naming and reforming injustices but about changing the economic, political, educational and cultural structures that produce them. Such movements cannot emerge fast enough given the relentless death machine that now dominates US society.

\section{Contemporary Threats to Democracy}

Everywhere we look today there is the looming threat of fascism and the eradication of those public spheres that produce the critical and energizing formative culture necessary for a radical democracy. Schools have been modeled after prisons, a range of social behaviors have been criminalized, especially in the public schools where young people are arrested for violating a dress code or doodling on their desk. A war is being waged not on poverty but on the poor as they are subject to laws that increasingly put them in jail for their debts or for simply being Black and poor. The ongoing killings and then demonization of unarmed Black youth and adults in cities throughout the United States by white police officers have made visible how a kind of military metaphysics now dominates US life. The police have been turned into soldiers who view the neighborhoods in which they operate as war zones. The earth is now viewed as a resource to be plundered, on part with the extraction of wealth, labor, hopes and dreams taken from other spheres of social life. A mad violence now rules US life.

Outfitted with full riot gear, submachine guns, armored vehicles and other lethal weapons imported from the battlefields of Iraq and Afghanistan, their mission is to assume battle-ready behavior. Is it any wonder that violence rather than painstaking, neighborhood police work and community dialogue and engagement 
becomes the norm for dealing with alleged 'criminals,' especially at a time when more and more behaviors are being criminalized? At the same time, violence becomes the DNA of a society that refuses to deal with larger structural issues such as massive inequality in wealth and power, and a government that now unapologetically serves the rich and powerful corporate interests, and makes violence the organizing principle of governance. The anger of those who have lost jobs, pensions, homes, and their dignity is now fodder for an emerging authoritarianism in the United States. Hate and fear-mongering become the currency of political discourse as a war on undocumented immigrants, labor unions, public goods, poor blacks, and Muslims moves from the margins to the center of power in the United States and other countries.

Barbarism is not simply a political concept; it is a practice forged in war and violence. Incapable of self-reflection, it smothers ethical considerations in the language of tactics so that the killing of children at home and abroad through the mechanisms of state terrorism is justified under the pretext of a military necessity a notion of fear forged in the bowels of the rising surveillance and punishing state. Turning poor neighborhoods into war zones is the metric of the financial elite and ethical zombies who without any semblance of moral conscience, merge power and violence, and wage war against those increasing populations now considered disposable. Under such circumstances, the distinction between civilians and combatants disappears. This is truly the logic of disposability central to state terrorism and the new totalitarianism.

It is hard to disagree with a growing consensus that what we are witnessing in the United States is the legacy of slavery and the criminalization of people of color reasserting itself in a society in which justice has been willingly and aggressively replaced by racial injustice. And it is precisely this militarization that should inform any analysis about the growing dangers of totalitarianism in the United States. Racist killings, the loss of privacy, the rise of the surveillance state, growing poverty and inequality, and the increasing corporatization of the commanding institutions of the United States point to something more than civil unrest, spying, police violence and other specific anti-democratic issues. What is truly at work here and unites all of these disparate issues is a growing threat of authoritarianism - or what might be otherwise called totalitarianism with elections. Trump's presidency and his racist and neoliberal policies mark a dark and dangerous turn in U.S. politics as it takes aim at democracy and the institutions and rules that make it possible.

But there is more at work in the madness of neoliberal capitalism than the oppression caused by its economic structures and the iniquitous gap in wealth, power and income that it produces. Americans also live in an age of death-dealing loneliness, isolation and militarized atomization. If you believe the popular press, loneliness is reaching epidemic proportions in wired advanced industrial societies. The usual suspect is the internet, which isolates people in the warm glow of the computer screen while reinforcing their own isolation and sense of loneliness. The 
Facebook notions of 'friends' and 'likes' become disembodied categories in which human beings disappear into the black hole of abstractions and empty signifiers. Yet, blaming the internet is too easy when one lives in a society in which any notion of dependence, compassion, mutuality, care for the other and sociality is undermined by a neoliberal ethic in which self-interest becomes the organizing principle of one's life and a survival-of-the fittest ethic breeds a culture that at best promotes an indifference to the plight of others and at worse a disdain for the less fortunate and a widespread culture of cruelty. Isolated individuals do not make up a healthy democratic society.

A more theoretical language produced by Marx talked about alienation as a separation from the fruits of one's labor and later through the Frankfurt School's notion of the culture of instrumental rationality, which has made a comeback in the new data-driven culture that is sweeping US society. Yet, traditional forms of alienation and the audit culture we now live in have evolved into something new and more poisonous. The culture of atomization and isolation under the current regime of neoliberalism is more extensive and governs the entirety of social life in a consumer-based society run by the demands of commerce and the financialization of everything. Isolation, privatization and the cold logic of instrumental rationality have created a new kind of social formation and social order in which it becomes difficult to form communal bonds, deep connections, a sense of intimacy and long-term commitments. Neoliberalism has created a rulingclass society of monsters for whom pain and suffering are now viewed as entertainment, warfare is viewed as a permanent state of existence, and militarism is viewed as the most powerful force shaping masculinity. Politics has taken an exit from ethics and thus the issue of social costs is divorced from any form of intervention in the world. This is the ideological metrics of political zombies. The keyword here is atomization and it is the curse of both neoliberal societies and democracy itself.

What must be remembered is that US politics is not simply representative of the death of reason and the emergence of a raw, unblemished, intense stupidity; it is also about the death of the formative cultures that make thinking possible. How else to imagine a president who claims he likes uneducated people, refused to read books, lies endlessly, and wages war on any vestige of the truth, evidence, and reason. Manufactured thoughtlessness produces not only an inattentiveness to the never-ending task of critique; it is the failure of conscience and moral witnessing. Reminiscent of Francisco Goya's 'The Sleep of Reason Produces Monsters,' the scourge of stupidity sweeping US culture represents a war against thought and critical agency, and flirts with a kind of fascistic irrationality, which lies at the heart of the spectacle of violence engulfing US society. The triumph of stupidity and manufactured ignorance is on full display in US political life and is matched by a savage militarization of the culture, an intensified level of daily violence and aggression, the withering of the social, and the withdrawal into private obsessions. 
Citizens have now become consumers, smothering in a fog of exaggerated selfinterest.

How else to explain the pure idiocy of a government under Trump that now permeates the political sphere with the climate change deniers, advocates of creationism, those urging a war against women's reproductive rights and the financial elite who are waging an assault on all forms of public and higher education, and so it goes. In a society in which social relations are reduced to a form of social combat and thinking collapses into a hyper-masculine adulation of self-interest and what Hannah Arendt called thoughtlessness (Arendt, 2001), there is no room for thinking, only the madness of violence, cruelty and misery, dressed up in the lie that the market should govern all social relations. But the posture of stupidity has another darker side; it becomes a way to flee from all forms of social responsibility and to hide the totalitarian interests that it legitimates. Power now thrives on stupidity, not simply the ignorance that ties the public to dominant forms of oppression, but to a form of stupidity that colonizes power and thrives on a form of mental and ethical tranquilization. James Baldwin was so right when he said, 'It is certain, in any case, that ignorance, allied with power, is the most ferocious enemy justice can have' (Baldwin, 1972: 149).

Absorbed in privatized orbits of consumption, commodification and display, Americans vicariously participate in the toxic pleasures of the authoritarian state. Violence has become the organizing force of a society driven by a noxious notion of privatization in which it becomes difficult for ideas to be lifted into the public realm. Under such circumstances, politics is eviscerated because it now supports a market-driven view of society that has turned its back on Hannah Arendt's insistence that 'Humanity is never acquired in solitude' (Arendt, 2013: 37). This violence against the social mimics not just the death of the radical imagination, but also a notion of banality made famous by Arendt who argued that at the root of totalitarianism was a kind of thoughtlessness, an inability to think, and a type of outrageous stupidity in which '[t]here's simply the reluctance ever to imagine what the other person is experiencing' (Arendt, 2013: 37).

Many Americans are asking questions about why there are not more people in the streets, as if economic turmoil or even the most overt expressions of state violence offer us a politics with guarantees. One reason, of course, is that the war on the imagination has been matched by the war on solidarity, communal relations and values that can't be commodified. We all live in war zones now, regimes marked by the most insidious violence and displays of greed, cruelty and lies. They are made all the worse because of the economic crisis; the new totalitarianism has not been matched by a crisis of ideas. Subjectivity has been stripped of any meaning, reduced to the gaze of public relations industries that feed the dispossession by extraction machine. Capitalism has reached its endpoint, blind to its death march. Fortunately, more and more young people and others are refusing to stand by and let state terrorism and market fundamentalism define their everyday lives. 
As John Dewey, Pierre Bourdieu, Noam Chomsky, Paulo Freire, Ellen Willis and others have reminded us there is no democracy without an informed public. This is a lesson the right wing took very seriously after the democratic uprisings of the 1960s. This is not a matter of blaming the public but of trying to understand the role of culture and power as a vital force in politics and how it is linked to massive inequities in wealth and income. The financial state promotes a form of ideological terrorism and the key issue is how to expose it, and dismantle its cultural apparatuses with the use of social media, new political formations, and ongoing collective educational and political struggles.

Relatedly, how can conditions be changed, such as the expanding forms of indebted citizenship and mass incarceration, which make students, low-income people and poor people of color disposable and unable to offer any collective resistance given their struggle either just to survive or suffer under harsh conditions of state repression? As Noam Chomsky, Jeffrey St. Clair, Angela Davis, Michelle Alexander, Paul Buchheit, Chris Hedges and others have pointed out, capitalism is spreading like a tumor in US society and the key is to cut out its ability to convince people that there are no other alternatives, that the market should govern all of social life, and that the government's only role is to protect the benefits of big business and the interests of the super-rich.

In the age of Trump, history neither informs the present nor haunts it with repressed memories of the past. It simply disappears. This is especially troubling when the 'mobilizing passions' of a fascist past now emerge in the unceasing stream of hate, bigotry, lies, and militarism that are endlessly circulated at the highest levels of the Trump administration and in powerful conservative media such as Fox News, Breitbart News, and conservative talk radio stations. These new digitally driven systems of production and consumption are no longer systems but ecologies that produce, shape, and sustain ideas, desires, and modes of agency with unprecedented power and influence. Informal education in the broadest sense appears increasingly to be on the side of tyranny. The first casualty of the Trump era is truth, the second is moral responsibility, the third is any vestige of justice, and the fourth is a massive increase in human misery and suffering for millions of Americans and others.

\section{Conclusion: Time to Flip the Script}

The argument that things will now get much worse and push people into action is politically naive because there are never any political guarantees of how people will act in the face of massive repression. They could, for all intents and purposes, go either left or right. And that is why such outcomes have to be struggled over both educationally and politically in the interests of creating a radical democratic society. Now is the time for working-class people to join with others to create new political formations, to rethink the possibilities of politics and to organize for both short-term gains and long-term fundamental changes. William Faulkner once 
remarked that we live with the ghosts of the past or to be more precise: 'The past is never dead. It's not even past.' Trump is living proof that we are not only living with the ghosts of a dark past, which can return. But it is also true that the ghosts of history can be critically engaged and transformed into a democratic politics for the future. The Nazi regime is more than a frozen moment in history. It is a warning from the past and a window into the growing threat Trumpism poses to democracy. The ghosts of fascism should terrify us, but most importantly they should educate us and imbue us with a spirit of civic justice and collective courage in the fight for a substantive and inclusive democracy. It is time to flip the script.

\section{REFERENCES}

Arendt, H. (2001). The origins of totalitarianism. New York: Houghton Mifflin Harcourt. Baldwin, J. (1972). No name in the street. New York: The Dial Press.

Arendt, H. (2013). The last interview and other conversations. Brooklyn, NY: Melville House Publishing.

Knott, M. L. (2011). Unlearning with Hannah Arendt. Trans. by David Dollenmayer. New York: Other Press.

HENRY A. GIROUX currently holds the McMaster University Chair for Scholarship in the Public Interest in the English and Cultural Studies Department. His most recent books include America at War with Itself (City Lights, 2017), The Public in Peril: Trump and the Menace of American Authoritarianism (Routledge, 2017), and American Nightmare: Facing the Challenge of Fascism (City Lights, 2018). Personal website: www.henryagiroux.com. 